Mateusz GRZESIAK ${ }^{1}$

\title{
E-BRANDING vs. TRADITIONAL BRANDING
}

Television, radio and press for many years reigned supreme in the marketing market, and made it possible to reach out effectively to a wide audience. However, we are now observing a decreasing effectiveness of traditional forms of brand communication (communication through $\mathrm{TV}$, in the press, on the radio or by the use of outdoor advertising). Young audiences - representatives of generations $\mathrm{Y}$ and $\mathrm{Z}$ - expect a completely different message from their parents or grandparents. They require a message to be as interactive as possible, as well as personalized, and they have much less trust in traditional forms of advertising. This all means that the importance of e-branding is constantly growing. The objective of this article is to describe the traditional ways of creating brands and of brand management, and to compare them with e-branding, taking into account the characteristics of forms as well as the most common distribution channels and ways of formulating messages. Traditional branding and e-branding are here discussed while remaining in the context of purchase choices, made by representatives of specific generations. Moreover, the article points to important differences in both described forms of brand creation, as well as - based on the newest examples of image campaigns and advertising for household names proves ebranding to have greater effectiveness in the contemporary world. This is happening because e-branding gives far greater possibilities of establishing personal rapports with customers, which is of great significance; but what is even more essential, as those from generation $\mathrm{Z}$ expect fully personalized announcements, this will start to dominate the market.

Keywords: branding, e-branding, traditional branding, brand awareness, creating a brand.

\section{INTRODUCTION}

Over the past decades TV, press and radio have allowed advertisers to reach the mass consumer, providing them with a controlled message. Still into the 1990s, a one-way marketing communication was applied - a brand usually built its image and its value through announcements directed at consumers via the press, television, radio or through traditional outdoor actions: on posters, billboards or leaflets. However, at present, in a world dominated by new technologies, the effectiveness of traditional announcements is decreasing. According to the McKinsey survey, the effectiveness of a TV commercial in the USA is now estimated as on the level of one third of the results that were achieved only 20 years ago. ${ }^{2}$ The Ehrenberg-Baas Institute for Science Marketing has conducted a survey showing that only every sixth advertisement broadcast on television is remembered and correctly associated with the brand six days after transmission. ${ }^{3}$ The audience of the

\footnotetext{
${ }^{1}$ MD Mateusz Grzesiak, a PhD student in the Department of Consumer Behaviour Research, Institute of Management, Warsaw School of Economics, ul. Madalińskiego 6/8, 02-554 Warsaw, Poland, e-mail: mg@starwayinstitute.com

${ }^{2}$ J. Kall, Branding on smartphone. Brand mobile communication. Wolters Kluwer SA, Warsaw 2015, p.11

${ }^{3}$ Ibidem, p.11.
} 
largest TV stations ${ }^{4}$ is also dwindling, as well as the average time spent in front of the television over twenty-four hours falling, especially in the youngest age groups of TV users. ${ }^{5}$ Customers demand the ability to interact, which is why besides traditional branding, e-branding is increasingly appearing. Effective communication requires that the brand is present in networks - as the research shows, the revenue growth of businesses that use social media while communicating with customers is a quarter higher than in the case of companies which do not use them. ${ }^{6}$ Communicating brands online allows interactivity, which makes it possible to collect feedback on the reaction to the produced message, and gather opinions of products, activities, services. The Internet facilitates communication with the online brand-consumer, enabling instant information sharing and a response to new emerging circumstances. Currently, the potential customer develops their opinion about the brand, assesses its credibility and forms an opinion whether the brand inspires confidence primarily on the basis of its image on the Internet.

\section{TRADITIONAL BRANDING}

As shown by Elliot and Percy a brand actually exists only in the mind of the consumer, and therefore its management (branding) is the management of one's perception. The brand is the entire range (not only the name, trademark, graphics, etc.), which seeks to assure buyers of something unique - either in its size, utility or symbolically, and thus influence the selection process by offering more than a 'no name' product ", i.e. one that does not have a clearly defined brand. ${ }^{7}$

The aim of both traditional branding and e-branding is: ${ }^{8}$

a) Providing information about the brand

Branding messages addressed to recipients have the aim not only to sell, but to make the same brand marketable by providing information about its usefulness.

b) Branding

Since people generally prefer what is known, the first step in building a brand image is to build awareness of it among its consumers.

a) Consumer involvement in a relationship with the brand

The purpose of branding is to create parallels to the line between the brand and receiver, which makes the brand become more attractive, desirable, worthy of recommendation in the recipient's eyes and the recipient, therefore, since the brand corresponds to his fantasies, becomes loyal to her.

\footnotetext{
${ }^{4}$ According to a study by Palmieri and Lee it showed that in the years 2010-14 the audience of four largest television stations in the United States decreased by $21 \%$ in the age group 18-49, source: http://www.bloomberg.com/bw/articles/ 2014-05-15 / tv-networks-fight-with-netflix-miniseries-revival (access: 14.10.2015).

${ }^{5}$ M. Połowianiuk, Television has no future, source: http://www.spidersweb.p1/2015/07/telewizja-nie-maprzyszlosci.html (access: 14.10.2015)

${ }^{6}$ J. Kall, op. cit., p. 167.

${ }^{7}$ Por. J. Kall, op. cit., p. 16.

${ }^{8}$ J. Kall, op. cit., p. 28.
} 


\section{TRADITIONAL BRANDING FEATURES}

The main distinguishing feature of traditional branding is a one-way communication channel with the customer. A narrow elite of broadcasters define the content of the message. Also linked to this is the monopoly of traditional media communications. In principle, in transmissions of this kind there is no place for content created by consumers, not counting those that pass the verification stage by the sender (for example on letter pages in magazines). A high cost of access to marketing tools is associated with this and as a result it confines access to a limited group of broadcasters. ${ }^{9}$

\section{DISTRIBUTION CHANNELS}

Traditional branding uses specific channels of communication: television, radio, press and outdoor advertising. Among traditional ways of branding may also be included sponsorship activities and organization of events and entertainments.For years' traditional media were successfully used in the process of creating a brand image. Globally, today the most often used medium in marketing is television, where market shares are $40 \%$, followed by promotion in the press (magazines and newspapers) - $25 \%$ of global advertising budgets. ${ }^{10}$ Although in the last decade a considerable outflow of funds towards new media has been observed, traditional marketing still accounts for almost $78 \%$ of the budget spent on advertising campaigns. ${ }^{11}$ Broadcasters happily use traditional channels of communication, in particular when branding is addressed to the older generations.

\section{Personal recommendation}

Personal recommendation is the most effective types of marketing. This concerns in particular the recommendation of friends. Research shows that $90 \%$ of consumers trust other people's recommendations. ${ }^{12}$ In the traditional range of marketing tools it can be found, among others, as buzz marketing. Its role is to reach out to the recipient with direct communication, which takes the form of "spontaneous" recommendation. The aim of this strategy is to create a "noise" around the promoted product, service or person. ${ }^{13}$ An example of such activities in the traditional form could be sending free products to volunteers (who then share the experience with friends) or finding a star celebrity who will become a brand ambassador, supporting the brand with their own image. Nevertheless, still the most effective form of marketing is friends' recommendations.

\section{Out-of-home commercials}

Creating images for $\mathrm{OOH}$ (Out-Of-Home) advertising is one of the most dominant tools of traditional branding. In Poland the money spent on outdoor campaigns for several years has remained at a similar level - in 2013 and 2014 it amounted to 450 million zlo-

\footnotetext{
${ }^{9}$ J. Królewski, P. Sala (red.), E-marketing. Contemporary trends. Starter Pack, PWN, Warsaw 2014, p. 13.

${ }^{10}$ J. Kall, op. cit., p. 194.

${ }^{11}$ Ibidem, p. 15.

${ }^{12}$ Ibidem, p. 17.

${ }^{13}$ G. M. Thomas, Building the buzz in the hive mind, „Journal of Consumer Behavior”, vol.4/2004, p. 64-72.
} 
tys. ${ }^{14}$ This implies an ability to reach preferred groups, primarily urban residents, where the use of outdoor advertising is rampant. This tool, of $\mathrm{OOH}$ advertising, allows a flexible adaptation to the target audience, by taking into account the criteria of the territory (a specific city, region, state, but also for example all the private universities in the country).The message coming from outdoor advertising focuses primarily on an image, so that the advertiser can determine precisely the image of the brand, promoted by the advertisements. A unique feature of outdoor advertising is its inevitable contact with the content by the recipient. It is not possible for the recipient not to perceive the communication flowing from the media, so inadvertently they memorize the broadcasted message. Apart from its traditional form, outdoor advertising can still be used in innovative branding campaigns. An example of this is the campaign for the IBM 2013, that used copyrighted elements of industrial design (e.g. shelters to protect pedestrians from the rain, benches) to place the brand logo, thus giving it an association with innovation and user-friendliness. ${ }^{15}$

\section{The internet as the dominant communication channel}

Technological development is ensuring that when creating a brand image, a greater and greater part of the potential target message recipients are Internet users. Especially among the younger generations, it is the dominant communication channel. Currently in the European Union, over $70 \%$ of people use the Internet, of which $47 \%$ do so via smartphones and tablets, with the Internet constantly at hand. ${ }^{16}$ The same thing is happening in Poland: $63 \%$ of Poles use the Internet ${ }^{17}$ and $71.9 \%$ of households have access to the network. Nearly two-fifths of Poles (39\%) also have an account in social media. ${ }^{18}$

Mindshare Poland research has determined that Poles spend every day: ${ }^{19}$

a) 3-4 hours in front of a laptop

b) 3 hours in front of a computer

c) 2.6 hours on a smartphone

d) 2 hours in front of a TV

e) 1.6 hours in front of a tablet

These data allow us to notice a huge difference in the time spent on television communication ( 2 hrs. per day) and online messages (in total on all devices with internet access -12.2 hrs. per day).

In developed countries - the US and the UK - over the past five years the amount of time spent on mobile devices has increased seven times. ${ }^{20}$ Devices with network access have a significant advantage over traditional media (television, radio, press).

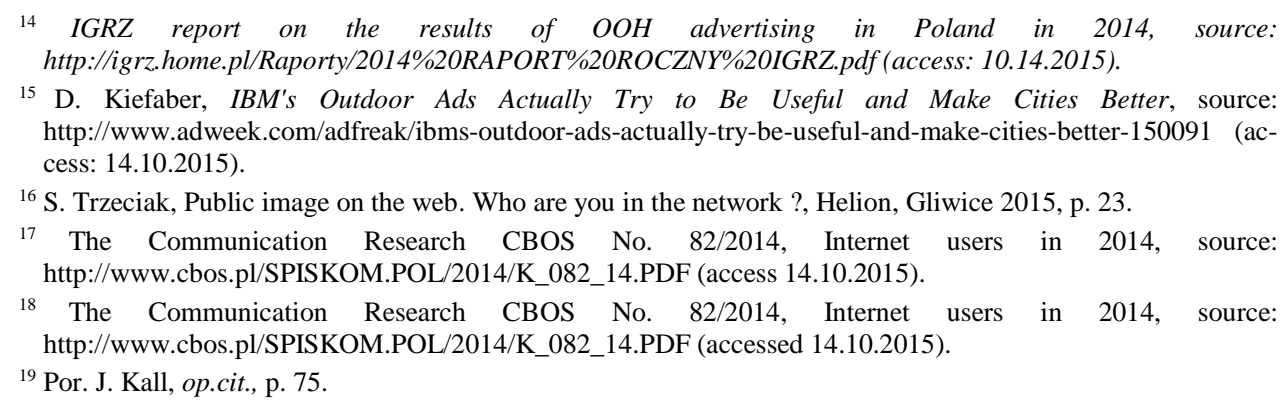


Because of this trend, consumers' decisions are also increasingly made based on information available on the Internet; users check goods and services on online forums, they rely on friends' recommendations, review the available channels of brand information on social media.

\section{E-BRANDING AND ITS FEATURES}

E-branding, like traditional branding, aims to create a specific brand image, but to create it and manage it by using the tools and opportunities offered by the internet. It has the same objectives as traditional branding but both forms are different in many aspects. Ebranding, unlike traditional branding is characterized by:

a) Constant presence

Traditional forms of marketing communications such as TV advertisements, in the press or on leaflets constitute an instantaneous message. Communication on the Internet is constant; all the contents are constantly on websites or social media profiles. They can be reached by every internet user from anywhere in the world. The cost of an online presence, as opposed to the traditional forms of branding is small, especially considering its stability.

b) Interactivity

Communication conducted on the internet allows one side of the communication (radio advertising, television speech) to interact with the customer ${ }^{21}$. Social media users can follow the channels of individual brands, they are kept informed about the activities of their favourite brands, have the opportunity to ask questions, evaluate, provide feedback on products and services so that businesses or individuals can react more quickly on user ratings, and then match up their actions and branding strategies to the needs and expectations of their customers.

c) Speed

Image campaigns in the traditional media ( $\mathrm{TV}$, press, outdoor advertising) require more regular planning in advance. Also, public relations and media relations need time. Building long-term relationships with journalists takes many months. On the Internet it is possible to have an effect immediately and any information sent over the network (a new post on a blog, newsletter, a new post on social media) goes to the audience right away. What's more, attractive messages spread through the network itself, thanks to the possibilities of copying, sharing and forwarding content. ${ }^{22}$

d) Constantly expanding audience

We are seeing a gradual decrease in the number of traditional media consumers, for example TV or the press. Meanwhile, the number of Internet users is constantly increasing.

e) Build trust

In traditional communication cases the range of recommendations of satisfied or dissatisfied customers was limited. Currently, the number of reached consumers expressing their opinions is much bigger, and as a result of this, any recommendation or negative

\footnotetext{
${ }^{20}$ Ibidem, p.77.

${ }^{21}$ S. Trzeciak, op. cit., p. 25.

${ }^{22}$ This is so called viral marketing.
} 
message can have a huge impact on the perception of the brand, and of creating its image. The Internet and especially social media allow consumers to organize themselves into strong pressure groups, which can promote the brand but also destroy them. That is why it is so important in e-branding to ensure the creation of a community around the brand, building trust, caring for loyal customers and having brand ambassadors, who in the event of a crisis may spontaneously help to provide brand support.

\section{E-BRANDING DISTRIBUTION CHANNELS}

\section{Social media}

Channels on social media are now widely used in communication. Their advantage is the possibility of interaction between users and the brand, but also the creation of relationships between supporters of the brand. DEI Worldwide Research and OTX have shown that $70 \%$ of consumers use social media to search for information about companies and their offers. $20 \%$ of them make purchase decisions on such information. According to research conducted by Synapse, customers who become friends or fans of a brand on Facebook are more loyal, and spend more on shopping than other customers. ${ }^{23}$ Tracking your favourite brands on social media is becoming increasingly popular. Four out of ten representatives of generation $\mathrm{Y}$ using social networking add to their favourites a brand's page; among generation $\mathrm{X}$ the figure is $31 \%$, and of representatives of the post-war babyboom generation $-27 \%$. Users want to be up to date, to know what is currently happening with a given brand. Representatives of generation $\mathrm{Y}$ instead of an ad expect the brands to create exciting services and offer access to sponsored content. ${ }^{24}$

\section{Content marketing}

The growing importance in branding gains of content marketing. The creation and distribution of high-quality information is one of the most effective marketing strategies in creating a brand image. Presenting professional and free content favours perception of the brand as being reliable and professional.

\section{Websites}

The website is the most important flagship of a brand. Its high visibility and easy availability increases reliability and customers' willingness to purchase services or products. ${ }^{25}$ In mechanisms for research positioning, websites are placed higher than social media as results on Google; this is why having a website is so crucial for a brand. Additionally, positioning mechanisms promote pages that contain words related to a search (for example, when searching for the word "coaching" not only results containing the single word coaching, but extensive substantive content are placed higher), as well as being user-friendly services, that are clear, transparent and have a mobile version. ${ }^{26}$

\footnotetext{
${ }^{23}$ Online branding - the need for new strategies, source: http://www.migomedia.pl/online-branding-potrzebanowych-strategii (access: 14.10. 2015.).

${ }^{24}$ J. Van den Bergh, M. Behrer, how to create brands that love generation Y?, Samo Sedno Edgard, Warsaw 2012, p. 38.

${ }^{25}$ Online branding - the need for new strategies, source: http://www.migomedia.pl/online-branding-potrzebanowych-strategii (access: 14.10. 2015.)

${ }^{26}$ B. Mazurkiewicz role of opinion leaders in informal communication, "Marketing and Market" No. 11/2014, p. 38.
} 


\section{Buzz marketing}

The terms "buzz marketing", "viral marketing", "word-of-mouth marketing", "evangelist marketing" and many others are sometimes used interchangeably. Currently, a significant part of recommendation communication takes place over networks, which is why brands so observantly follow opinions as they appear on social media. Research shows that $43 \%$ of teenagers aged 15-24 recommend their friends to try a brand. Buzz marketing in generation $\mathrm{Y}$ has a huge impact on consumer decisions - up to $60 \%$ of people manage to convince another to try a product for the first time. ${ }^{27}$

\section{BRANDING AND E-BRANDING IN THE CONTEXT OF CHOICES MADE BY THE GENERATIONS}

\section{The silent generation}

Variously called the silent generation, depression generation, the swing generation or traditionalists. People born in the years 1928-1945, the children of World War II and the period of the Great Depression, the nickname "silent" refers to the conformist attitude, showing a big difference between them and the loud expression of their beliefs of the next generations. ${ }^{28}$ They value savings and ethics in business, and an important value for them is social security and family ties. They rely on proven, trusted products and services. Their preferred communication channels are radio, television, billboards, magazines, traditional mail and meetings with experts. ${ }^{29}$

\section{The post-war baby boom generation}

This describes people born in the years 1946 to 1964, just after the end of World War II. Other names of this generation are the love generation, Woodstock generation, baby boomers and the sandwich generation. They grew up in a period of economic growth, so did not have to be afraid of unemployment. They enjoyed greater freedom, leisure, and thus they are more flexible and easier adapt. ${ }^{30}$ They are characterized by a need for selfsufficiency. The representatives of this generation were the creators of the first personal computers and mobile devices. They appreciate individuality, freedom and live according to their own rules. Their goal in life is prosperity, good health and happiness. They have less trust in authorities. Television is still the main and preferred medium of communication but they also benefit from the internet, though use it mainly for the development of society; to a small extent they use it as a tool to support decision-making processes when it comes to and selecting a brand ${ }^{31}$ and purchasing.

\footnotetext{
${ }^{27}$ J. van den Bergh, M. Behrer, op. cit., p. 53.

${ }^{28}$ Ibidem, p. 22.

${ }^{29}$ K. C. Williams, R. A. Page, Marketing to the Generations, "Journal of Behavioral Studies in Business", April 2011, p. 3, source http://www.aabri.com/manuscripts/10575.pdf (access: 14.10.2015).

${ }^{30}$ M. McCrindle, D. Hooper, Generation Y. Attracting, engaging and leading a new generation at work, source: http://avpma.ava.com.au/sites/default/files/AVPMA_website/resources/5.2\%20Generation\%20Y\%20$\% 20$ Attracting,\%20Engaging\%20\%26\%20Leading\%20a\%20New\%20Generation\%20at\%20Work.pdf $\quad$ (access: 14.10.2015).

${ }^{31}$ K. C. Williams, R. A. Page, op. cit., p. 6.
} 


\section{Generation X}

Generation X consists of people born in the years 1965 to 1979; they are also called: baby busters, a lost generation, the invisible generation, the "why me" generation. They began their careers in the early 90s of the twentieth century, during the recession, mass layoffs and economic transformation. They are characterized by great individualism and a general pessimism. They are interested in making money using the rule of "buy cheap, sell expensive." Inclined to believe to a much greater extent than any other generation in the truth of advertising, they perceive TV commercials as attractive. ${ }^{32}$ Television is their preferred communication channel, but they also use the Internet to educate themselves and obtain information about products.

\section{Generation $Y$}

This consists of people born between 1980 to1996, the first generation growing up in the era of the new millennium. Otherwise called the Millennium generation, the Why Generation, Net generation, or the generation of networks. They have a lot of knowledge about marketing, as advertising and media have accompanied them since birth, and because of this they are relatively resistant to advertising messages. New technologies are of great importance to them. ${ }^{33}$ Representatives of the generation $\mathrm{Y}$ have: environmental awareness, a distrust of the media, make intensive use of electronic media, have awareness of global trends and use the Internet in making a purchasing decision. ${ }^{34}$ Generation $\mathrm{Y}$, on the basis of research conducted mainly in the United States is now considered the largest market segment in the world, and its spending power is constantly rising. At the same time the results of the research show that Generation Y does not tolerate bad experiences with brands; all negative situations can immediately lead to great loss of trust and loyalty. For Generation Y brand authenticity is very important, and its integrity and honesty - only these provide the potential opportunity of long-term consumer loyalty to the brand. ${ }^{35}$ At the same time the results of the research show that Generation Y does not tolerate bad experiences with brands, all negative situations can immediately lead to a loss of trust and loyalty. For Generation Y very important is brand authenticity and its integrity and honesty - only they provide a potential opportunity for long-term consumer loyalty to the brand.$^{36}$ They use the television selectively, focusing exclusively on programs dedicated for them. A new, emerging distribution channel for this generation is product placement in computer games. ${ }^{37}$

\footnotetext{
${ }^{32}$ J. van den Bergh, M. Behrer, op. cit., p. 22.

${ }^{33}$ Ibidem, s. 22.

${ }^{34}$ P. Paul, Getting inside Gen Y, "American Demographics", no. 23(9), p. 42-49.

${ }^{35}$ E. Gołąb-Andrzejak Loyalty in the information society on the example of "Millennials", "Marketing and Market" no. 11/2014, p.13.

${ }^{36}$ J. A. Parris, Is your self-service Millennial friendly?, "Speech Technology", January/February 2010, source: http://www.speechtechmag.com/Articles/Column/Inside-Outsourcing/Is-Your-Self-Service-MillennialFriendly-60407.aspx (access: 14.10.2015)

${ }^{37}$ K. C. Williams, R. A. Page, op. cit., p. 9.
} 


\section{Generation $\mathbf{Z}$}

This generation includes all born after 1996, also called the iGeneration, not only due to their attachment to iPods, iPhones and iPads but also because of their great need for individualization. Personalization of communication is the basis of thinking of this generation. ${ }^{38}$

\section{TRADITIONAL BRANDING, E-BRANDING vs. BRAND AWARENESS}

American research shows that online advertising increases spontaneous brand awareness by 4\%, while research in Germany for MSN, conducted by The European Interactive Advertising Association, has revealed that companies that advertise on the Internet increase their range by an additional $16 \% .{ }^{39}$ In contrast, the results of "The Branding Value of A Search's Page One" from 2012 reveal that the most significant increase in building brand awareness, as much as $30 \%$, occurs when a brand appears simultaneously in the organic results in a search engine and the results shown on the first screen without scrolling. ${ }^{40}$

\section{McDonald's}

As an example of the effectiveness of e-branding being more effective compared to traditional branding, we can look at the sandwich advertising campaign conducted by McDonald's in the UK. A transfer of $20 \%$ of the budget from off-line advertising to online advertising resulted in a $13 \%$ increase in product awareness. If this $20 \%$ had been spent on traditional media, the increasing awareness of the product would be only $2 \% .{ }^{41}$

\section{Pepsi}

Pepsi followed a similar path. In 2010 they abandoned traditional advertising during the final Superbowl match, and funds to an amount of \$ 20 million were spent on a big public campaign, the Pepsi Refresh Project. They created a web platform for the promotion of local projects which required funding. Each platform user could create an account on the site and upload a video of their own project, collecting votes from other users. The winning projects received funding to the amount of 5000-25,000 dollars. Because users gave their votes to the projects they found most interesting, Pepsi could better understand the needs and preferences of their audience. The activities of the Pepsi Refresh Project involved well-known the American actress, star of the TV series "Desperate Housewives", Eva Longoria, supporting the project for the non-profit organization Address Contra El Cancer. ${ }^{42}$ The project Pepsi perfectly tied in with the expectations of generation $\mathrm{Y}$, and was a good alternative to traditional advertising, of which this generation is wary and it engaged users, meeting the criteria of interactivity.

\footnotetext{
${ }^{38}$ J. van den Bergh, M. Behrer M., op. cit., p. 24.

39 Online branding - need of new strategies, source: http://www.migomedia.pl/online-branding-potrzebanowych-strategii (access: 14.10. 2015r.).

${ }^{40}$ Ibidem.

${ }^{41}$ Ibidem.

${ }^{42}$ J. van den Bergh, M. Behrer M., op. cit., p. 45-46.
} 


\section{True Blood}

The premiere of the third season of the TV series "True Blood", produced by HBO, as opposed to the previous series, was promoted on the network. The campaign was addressed to network users Flixster film, and on Variety on mobile devices. Touching the screen while browsing caused an imprint of a bloody mark on the screen, and subsequent blood dripping down the screen. Then appeared a banner encouraging the viewer to see the trailer for the new season of the show. The viewership of the third season of "True Blood" increased by $38 \%$ compared to the previous season. ${ }^{43}$ This may be related to the fact that the advertising met the criteria of innovation, as well as, by using the mobile channel, it went to the representatives of the Y generation, which uses much less television.

\section{Nike}

In 2004 sportswear manufacturer Nike developed an application for runners, Nike +, which after downloading it on your smartphone enabled the consumer to store information about each training session, and publish it on the site nikeplus.com. The technology was in sync with iPods and iPhones. The site nikeplus.com users could benefit from specific training programs, compare achievements and compete with other users. Through Nike +, Nike increased the company's turnover - with their $48 \%$ market share of the athletic footwear rising to $61 \%$ within two years. Thanks to this service many users convinced themselves of the brand and its products. ${ }^{44}$ The success of the image campaign was associated first with the fact connection to a different brand, by many considered to be a cult, that is Apple. Secondly, not without significance was the fact that it provided users with a free application, and the possibility of sharing results which has helped build a community around the brand.

\section{VISIBLE TRENDS AND FORECASTS FOR THE FUTURE}

These examples give reason to believe that the trend away from traditional branding for e-branding will continue. Comments by generations $\mathrm{Y}$ and $\mathrm{Z}$ show they are not able to be attracted by the traditional image campaigns on television, newspapers or radio. It is related in particular to the fact that the generation $\mathrm{Y}$ and $\mathrm{Z}$ are focused on new technologies; what is more generation $\mathrm{Z}$ does not know the time without using the Internet, and the network is their basic medium from which they get information about the world. It is generations $\mathrm{Y}$ and $\mathrm{Z}$ that are now the largest consumer market brands.It seems that in the framework of e-branding the trend towards mobile advertising will strengthen, addressed to users of smartphones and tablets. With each passing year the lifetime of these devices increases for consumers, so mobile advertising can reach them at all, at any time - while watching a show, traveling by public transport or shopping. E-branding also gives much greater opportunities to establish personal relationships with customers, which will be of great importance when the generation $\mathrm{Z}$, depending on a fully personalized messages, will dominate the market.

\footnotetext{
${ }^{43}$ J. Kall, op. cit., p. 129.

${ }^{44}$ Ibidem, p. 35.
} 


\section{SUMMARY}

Network media and social media have become the primary sources of knowledge about brands and products for many consumers. They also play a key role in the discovery of new brands through recommendations from friends and unidentified network users. Nowadays, the creation of a brand campaign is not enough. The real driving force of a brand today are loyal consumers, people who are well aware of a brand and are eager to use its products or services. Opinions and recommendations of friends can have a far greater impact on consumers' decisions than advertising. A good reputation has always been important for the image of a brand, but now the owners of the brands have little effect on the nature of comments on their products and services in the network, so hence the thinking that the image is so important. A strong brand has a bond with the consumer and makes an interesting offer. Marketing activities of brands should arouse interest and stimulate positive opinions about the brand, especially on the networks.

\section{LITERATURE}

[1] Gołąb-Andrzejak Edyta. 2014. ,, Loyalty in the information society on the example of "Millennials", Marketing i Rynek 11: 11-21.

[2] Kall Jacek. 2015. „Branding on smartphone. Brand mobile communication”. Warsaw: Wolters Kluwer SA.

[3] Kiefaber David. 2013. "IBM's Outdoor Ads Actually Try to Be Useful and Make Cities Better”. source: http://www.adweek.com/adfreak/ibms-outdoor-ads-actually-try-be-useful-andmake-cities-better-150091 (access: 14.10.2015).

[4] „CBOS Communication Research No. 82/2014: Internet users”. Source: http://www.cbos.pl/SPISKOM.POL/2014/K_082_14.PDF (access14.10.2015).

[5] Królewski Jarosław, Sala Paweł (red.).2014. „E-marketing. Contemporary trends. Starter pack". Warsaw: PWN.

[6] Mazurkiewicz Bartosz. 2014. „The role of leaders' opinion in informal communication.”

[7] McCrindle Mark, Hooper Danica. 2007. "Generation Y. Attracting, engaging and leading a new generation at work". Source:

http://avpma.ava.com.au/sites/default/files/AVPMA_website/resources/5.2\%20Generation\%2 0 Y $\% 20 \% 20$ Attracting, $\% 20$ Engaging $\% 20 \% 26 \% 20$ Leading $\% 20 a \% 20$ New $\% 20$ Generation $\% 20$ at\%20Work.pdf (access: 14.10.2015).

[8] Parris Jo Ann. 2010. "Is your self-service Millennial friendly?". Speech Technology. Source: http://www.speechtechmag.com/Articles/Column/Inside-Outsourcing/Is-Your-Self-ServiceMillennial-Friendly-60407.aspx (access: 14.10.2015).

[9] Paul Pamela. 2001. "Getting inside Gen Y". American Demographics 23(9): 42-49.

[10] Połowianiuk Marcin. 2015. „Television has no future”. source: http://www.spidersweb.pl/2015/07/telewizja-nie-ma-przyszlosci.html(access: 14.10.2015)

[11] „IGRZ report on the results of OOH advertising in Poland in 2014 Report”. source: http://igrz. home.pl/Raporty/2014\%20RAPORT\%20ROCZNY\%20IGRZ.pdf(access: 14.10.2015).

[12] Thomas Greg Metz. 2004. "Building the buzz in the hive mind". Journal of Consumer Behaviour 4: 64-72.

[13] Trzeciak Sergiusz. 2015. „Public image on the web. Who are you online?”. Gliwice: Helion.

[14] „Online branding - the need of new strategies”. source: http://www.migomedia.pl/onlinebranding-potrzeba-nowych-strategii (access: 14.10. 2015r.).

[15] Van den Bergh Joeri, Behrer Mattias. 2012. „How to create brands that generation Y will love?". Warsaw: Samo Sedno Edgard.

[16] Williams Kaylene C., Page Robert A. 2011. "Marketing to the Generations", Journal of Behavioral Studies in Business". source: http://www.aabri.com/manuscripts/10575.pdf (access 14.10.2015). 


\section{E-BRANDING A BRANDING TRADYCYJNY}

Telewizja, radio oraz prasa przez wiele lat niepodzielnie panowały na marketingowym rynku i pozwalały efektywnie docierać do szerokiego grona odbiorców. Jednakże obecnie obserwujemy spadek skuteczności tradycyjnych form komunikacji marki (poprzez komunikaty w telewizji, na łamach prasy, w rozgłośniach radiowych czy z wykorzystaniem reklam outdoorowych). Młodsi odbiorcy - przedstawiciele pokolenia Y i Z - oczekują od komunikatów czegoś zupełnie innego niż ich rodzice czy dziadkowe. Wymagają, aby przekaz był możliwie jak najbardziej interaktywny i zindywidualizowany oraz mają znacznie mniejsze zaufanie do tradycyjnych form reklamy. Wszystko to sprawia, że znaczenie e-brandingu stale rośnie. Celem niniejszego artykułu jest próba opisania tradycyjnego sposobu kreowania i zarządzania marką oraz porównania go z e-brandingiem, uwzględniając cechy obu jego form, najczęstsze kanały dystrybucji, a także sposoby formułowania komunikatów. Tradycyjny branding oraz e-branding omówione zostają w kontekście wyborów zakupowych dokonywanych przez przedstawicieli poszczególnych generacji. Artykuł wskazuje ponadto na istotne różnice $\mathrm{w}$ obu przedstawionych formach kreowania marki, a także - w oparciu o najnowsze przykłady kampanii wizerunkowych i reklamowych znanych marek - dowodzi większej skuteczności e-brandingu we współczesnym świecie. Dzieje się tak dlatego, że ebranding daje o wiele większe możliwości nawiązywania osobistych relacji z klientami, co już ma duże znaczenie, a stanie się jeszcze istotniejsze, gdy pokolenie Z, oczekujące pełnej personalizacji komunikatów, zacznie dominować na rynku.

Słowa kluczowe: branding, e-branding, branding tradycyjny, świadomość marki, kreowanie marki.

DOI: $10.7862 /$ rz.2015.mmr.56

Tekst złożono w redakcji: październik 2015

Przyjęto do druku: styczeń 2016 